\title{
Red deer and cattle diet composition in La Pampa, Argentina
}

\author{
A. J. PORDOMINGO AND T. RUCCI
}

Authors are research scientists of Instituto Nacional de Tecnología Agropecuaria, INTA Anguil, C.C. 11, Anguil (6326), La Pampa, Argentina.

\begin{abstract}
Presence of 2 large herbivores in the same rangeland makes assessment of proper stocking rates and management practices rather complex. This study evaluated composition and overlap of red deer and cattle diets in a semiarid, temperate rangeland of La Pampa province, Argentina. Deer and cattle diets were estimated by microhistological analysis of feces. Fifteen samples were collected for cattle and deer during fall, winter, spring, and summer of 1994/95 (Period 1) and the same seasons of 1996/97 (Period 2). Red deer and cattle diets were different $(P<0.01)$ within each sampling season. Diets were also different $(P<0.01)$ among sampling seasons within each animal species. Red deer were better shrub users than cattle. Deer consumed more than 4 times the amount of shrubs than cattle during all seasons. Shrubs accounted for 28 to $50 \%$ of deer diets in most seasons, and from 6 to $12 \%$ in cattle diets. Forbs were a variable component of diets. However, red deer harvested more forbs than cattle in most sampling seasons $(P<0.05)$. Cattle were better grass users than red deer. Cows consumed more $(P<0.05)$ perennial graminoids in all seasons, and based their diet on cool-season perennial grasses. A trend for red deer to behave as an intermediate feeder, compared with cattle could be suggested. In the environment of our study, deer and cattle diet overlap varied greatly depending on availability of palatable fractions of forbs, shrubs, and grasses. Forb and shrub regrowth would reduce the diet overlap.
\end{abstract}

Key Words: Browsing, intermediate feeders, grass users, rangeland use, range diets, multi-species programs

Presence of 2 large herbivores in a confined native area makes assessment of proper stocking rates and management practices complex. Degree of diet overlap and conflicts of management for each animal species may result in lower productivity than expected. On the other hand, more than 1 large herbivore may better explore and use the plant community at several strata, and achieve greater productivity. Association and tolerance among animal species affect interactions and the way an ecosystem is utilized (Ellis et al. 1976). Diet overlap may not be detrimental to the rangeland if the range resource and its responses to grazing are understood (Vavra et al. 1989).

This research was funded by Instituto Nacional de Tecnología Agropecuaria. INTA Anguil, La Pampa. Authors wish to thank Sonia Velilla for the microhistological analysis; owners of the red deer and cattle operation "La Legua", Mr. Walter Perez and ranch personnel for their cooperation during field data collection. Manuscript accepted 6 Mar. 2000.
Resumen

La presencia de 2 herbívoros grandes en el mismo pastizal complica la determinación de carga animal y la adecuación de las prácticas de manejo. Este estudio evaluó la composición y sobreposición de dietas de ciervo colorado y ganado bovino en un pastizal templado, semiárido de la provincia de La Pampa, Argentina. Las dietas de ambas especies fueron estimadas a través de análisis micro-histológico de heces. Quince muestras compuestas fueron recogidas por especie animal en otoño, invierno, primavera y verano de 1994/95 (Período 1) y también en las mismas estaciones de 1996/97 (Período 2). Las dietas de ciervo colorado y bovino fueron diferentes $(P<0.001)$ dentro de cada estación de muestreo. También fueron también diferentes $(P<0.01)$ entre estaciones para cada especie animal. El ciervo hizo mayor uso del arbusto que el bovino. Consumió más que 4 veces la cantidad de arbustos que el vacuno en todas las estaciones. Esa clase vegetal aportó entre el 28 y el $50 \%$ de la dieta de los ciervos en la mayoría de las estaciones, y entre el 6 y el $12 \%$ de la dieta de los vacunos. La presencia de herbáceas anuales latifoliadas fue variable en las dietas de ambas especies, pero prevaleció en la de ciervo colorado $(\mathbf{P}<0.05)$. Por su parte, el bovino hizo mayor uso de las gramíneas. El consumo de gramíneas perennes fue superior en bovinos. En particular, la clase correspondiente a gramíneas perennes invernales constituyó la base de su dieta a lo largo del año. En el ambiente de este estudio, las sobreposición de dietas dependió de la disponibilidad de fracciones palatables de arbustos, herbáceas latifoliadas y gramíneas. La presencia de herbáceas latifoliadas, y rebrote de arbustos redujo el grado de sobreposición. La información recogida sugiere un comportamiento ramoneador del ciervo colorado, comparado con el vacuno, en el pastizal pampeano.

Red deer (Cervus elaphus) were introduced to Argentina from Europe into the native environment of temperate and cold regions. Red deer populations increased and the species naturalized over the years. Current knowledge suggests that red deer have a high adaptable capacity to use available forage if diversity in the plant community is high (Kinuthia et al. 1992). The present study compares the botanical diet composition of red deer with cattle (Bos taurus) in a deer-fenced deer-cattle operation, based on rangeland of caldén (Prosopis caldenia Burkart) forest of Argentina. 


\section{Materials and Methods}

\section{Study Area}

The study was conducted in the southcentral region of La Pampa Province (Latitude $37^{\circ} 30^{\prime} \mathrm{S}$, Longitude $64^{\circ} 8^{\prime} \mathrm{W}$ ). Elevation ranges from 260 to $200 \mathrm{~m}$ from North-West (NW) to South-East (SE). The area receives an annual precipitation of about $519 \pm 177 \mathrm{~mm}$, with no snowfall (Roberto et al. 1994). Most precipitation falls in the spring and fall with the majority of forage growth occurring in these seasons. The landscape is defined by mesas and valleys running ordered from NW to SE, interspersed with sandy rolling hills. Soils are classified as Entic Haplustolls and Typic Ustipsamments, developed on sandstone, loess and limestone (Cano 1980). Discontinuous pretrocalcic horizons are present at varing depths, between 0.6 and 1-m deep (Cano 1980).

\section{Vegetation and use}

The area is a forest comprised of caldén (Prosopis caldenia Burkart), the dominant tree species. Under the tree canopy, there is a lower layer of woody species integrated by shrubs, including piquillín (Condalia microphylla Cavanilles), tramontana (Ephedra triandra Tul. em J. H. Hunziker), Bredemeyera microphila (Gris.) Hieron. ex Lorentz and Niederlein, pichana (Cassia aphylla Cavanilles), molle [Schinus fasciculatus (Griseb.) Johnston], llaollín (Lycium chilense Miers], piquillín de víbora (Lysium gilliesianum Miers), brusquilla [Discaria longispina (Hook. at Arn.) Miers], Sphaeralcea crispa Baker, tomillo [Acantholippia seriphioides (A. Gray) Moldenke], and mata trigo (Baccharis gilliesii A. Gray). The most conspicuous forb species are olivillo (Hyalis argentea Don. var. Latisquama Cabrera), peludilla (Plantago patagonica Jacquin), yerba de oveja (Baccharis ulicina Hooker et Arnott), trébol de carretilla [Medicago minima (L.) Grufberg], cardo ruso (Salsola cali Linné), Rynchosia senna Gill. Ex Hook. et Arn., Nierenbergia aris tata (Sweet), revienta cavallo (Solanum eleagnifolium Cavanilles), Solanum chenopodium (Cavanilles), Triodanis biflora (Ruiz et Pavón) Greene, quinoa (Chenopodium albun Linné), and rama negra [Conyza bonariensis (L.) Cronquist] (Cano 1980).

Cool-season and warm-season perennial grasses comprise most of the of the forage supply in the region (Cano 1980). Fechilla negra [Piptochaetium napostaense (Speg.) Hackel] and fechilla fina (Stipa tenuis Philippi) are the winter and spring dominant cool-season perennial grasses. Another perennial grass, unquillo (Poa ligularis Nees ex Steudel), is a companion species, highly palatable but less tolerant to grazing than the other 2. Overgrazed fields are dominated by the low-palatable coolseason perennial grasses such as paja blanca (Stipa gynerioides Philippi), paja fina (Stipa tenuissima Trinius) and pasto puna (Stipa brachychaeta Godron) (Cano 1980).

Important warm-season perennial grass species are pasto plateado (Digitaria cali fornica (Benth.) Henrard], penacho blanco [Bothriochloa springfieldii (Gould) Parodi], Mulhenbergia gracillima Torr., Sporobolus cryptandrus (Torr.) A. Gray, pasto fino [Schismus barbatus (L.) Thellung] and cola de zorro [Setaria leucopila (Scrib. et Merrill) Schumann]. Main cool-season annual grass species present in the area are cebadilla (Bromus brevis Nees), Briza sub aristata (Lamarck), and centenillo (Hordeum stenostachys Godron). Relevant warm season annual grass species are paja voladora (Panicum vergii Arechavaleta), gramón [Cynodon dactylon (L.) Persoon], and roseta [Cenchrus pauciflorus Bentham] (Cano 1980).

Cow-calf production is the region's main enterprise, based on yearlong native range use. The forest canopy increases in valleys and on side hills where soil depth is not as limiting as on mesas and hilltops. The more forested areas provide winter native range. Sandy areas and mesas are dominated by warm-season perennial grasses and are used as summer native range. Transition fields are used in different seasons as they suit production programs.

\section{Study site}

The study was conducted in a deerfenced 2,500-ha ranch in the center of the mentioned area. Historically, the ranch maintained a cow-calf operation, and since 1990 a red deer program was included. The ranch has run 400 cows in the past. At present, it runs 350 cows and 300 red deer.

\section{Sampling}

Deer and cattle diets were estimated by identification of plant species and their relative proportions by microhistological analysis of fecal samples. Fifteen composite fecal samples were collected from cattle and red deer each season, during 2 sampling periods (1 and 2). Sampling seasons were defined as fall, winter, and spring of 1994 and summer of 1995 for Period 1, and the same seasons of 1996 and 1997 for Period 2. Collection seasons were established based on phenological stages of dominant species (Cano 1980). Periods 1 and 2 were different in total rainfall and distribution (Table 1), which added climate variability. A wild fire inlate summer of 1995 caused a temporary disturbance.

Individual samples were kept frozen and analyzed separately. Samples were thawed, oven dried at $50^{\circ} \mathrm{C}$, and ground in a Wiley mill (1-mm screen). Samples were prepared for reading following the methodology described by Holechek et al. (1982) and botanical composition was estimated according to Sparks and Malechek (1968). Frequency of occurrence of each species in each sample was converted to relative density and used to calculate proportions in the diet (Holechek and Gross 1982). For analysis and discussion, species were grouped into plant species classes: cool-season perennial grasses, warm-season perennial grasses, shrubs, forbs, and annual grasses.

\section{Statistical analysis}

Data were subjected to analysis of variance with split-plot models including animal species in the main plot, and sampling season in the subplot. Multivariate analysis of variance for total diet comparisons between animal species by season within period was performed. Data of animal diets by plant classes or relevant individual plant species were submitted to analysis of variance (GLM, SAS 1985). Dietary overlap was estimated by period and season using the quantitative similarity index as described by Bray and Curtis (cited by Müeller-Dombois and Ellenberg 1974).

\section{Results}

\section{Animal differences by season \\ Fall diets}

Year of 1994 began with a dry summer. It was a dry year compared with 1996 (Table 1). Cool-season grasses delayed regrowth and annual forbs increased presence in diets. During fall of 1994, red deer fed on

Table 1. Seasonal precipitation $(\mathrm{mm})$ during the years of study in semiarid South-central La Pampa, Argentina

\begin{tabular}{lccll}
\hline \hline & 1994 & 1995 & 1996 & 1997 \\
\hline Summer & 173 & 249 & 654 & 179 \\
Fall & 101 & 67 & 109 & \\
Winter & 126 & 20.5 & 68 & \\
Spring & 141 & 185 & 423 & \\
\hline Annual total & 541 & 521.5 & 954 & \\
\hline
\end{tabular}


Table 2. Relative botanical composition $(\%)$ of red deer and beef cattle diets of a native range of South-central La Pampa ${ }^{1,2}$.

\begin{tabular}{|c|c|c|c|c|}
\hline Period 1 & Fall & Winter & Spring & Summer \\
\hline \multicolumn{5}{|l|}{ Shrubs } \\
\hline Cattle & $3.7 \pm 13.2$ & $7.2 \pm 6.67$ & $3.8 \pm 4.3$ & $18.2 \pm 6.7$ \\
\hline Red deer & $33 \pm 10.2$ & $38.7 \pm 5.3$ & $49.8 \pm 4.3$ & $41.8 \pm 6.7$ \\
\hline $\mathrm{P}^{3}$ & 0.076 & 0.0034 & 0.0001 & 0.038 \\
\hline \multicolumn{5}{|c|}{ Cool-season perennial grasses } \\
\hline Cattle & $62.3 \pm 4.8$ & $73.0 \pm 5.4$ & $46.4 \pm 1.6$ & $41.0 \pm 3.4$ \\
\hline Red deer & $2.6 \pm 3.7$ & $38.6 \pm 4.3$ & $4.2 \pm 1.6$ & $10.4 \pm 3.4$ \\
\hline $\mathrm{P}$ & 0.002 & 0.0004 & 0.0001 & 0.0002 \\
\hline \multicolumn{5}{|c|}{ Warm-season perennial grasses } \\
\hline Cattle & $16 \pm 3.8$ & $4.4 \pm 1.0$ & $35 \pm 3.8$ & $36.8 \pm 5.6$ \\
\hline Red deer & $6.8 \pm 2.3$ & $1.4 \pm 0.8$ & $31.6 \pm 3.8$ & $42 \pm 5.6$ \\
\hline $\mathrm{P}$ & 0.09 & 0.04 & 0.55 & 0.53 \\
\hline \multicolumn{5}{|c|}{ Annual grasses } \\
\hline Cattle & $3 \pm 0.5$ & $1.4 \pm 0.5$ & $9.6 \pm 1.1$ & $0.2 \pm 0.4$ \\
\hline Red deer & $1.2 \pm 0.4$ & $1.4 \pm 0.4$ & $7.6 \pm 1.1$ & $1.8 \pm 0.4$ \\
\hline $\mathrm{P}$ & 0.04 & 0.97 & 0.22 & 0.02 \\
\hline \multicolumn{5}{|l|}{ Forbs } \\
\hline Cattle & $15 \pm 13$ & $14 \pm 5.6$ & $5.2 \pm 1.4$ & $3.8 \pm 1.6$ \\
\hline Red deer & $56.4 \pm 10$ & $19.9 \pm 4.4$ & $6.8 \pm 1.4$ & $4 \pm 1.6$ \\
\hline $\mathrm{P}$ & 0.02 & 0.42 & 0.44 & 0.93 \\
\hline Period 2 & Fall & Winter & Spring & Summer \\
\hline \multicolumn{5}{|l|}{ Shrubs } \\
\hline Cattle & $12.4 \pm 4.2$ & $2.8 \pm 2.7$ & $17 \pm 4.2$ & $4.8 \pm 7.5$ \\
\hline Red deer & $42.4 \pm 4.2$ & $12.8 \pm 2.7$ & $29.4 \pm 4.2$ & $54.8 \pm 7.5$ \\
\hline $\mathrm{P}$ & 0.001 & 0.031 & 0.07 & 0.0015 \\
\hline \multicolumn{5}{|c|}{ Cool-season perennial grasses } \\
\hline Cattle & $75.4 \pm 3.3$ & $88 \pm 3.6$ & $45.2 \pm 4.7$ & $58.6 \pm 4.9$ \\
\hline Red deer & $41.6 \pm 3.3$ & $57.6 \pm 3.6$ & $20.2 \pm 4.7$ & $15.4 \pm 4.9$ \\
\hline $\mathrm{P}$ & 0.0001 & 0.0003 & 0.006 & 0.0002 \\
\hline \multicolumn{5}{|c|}{ Warm-season perennial grasses } \\
\hline Cattle & $1.6 \pm 0.4$ & $3 \pm 0.9$ & $13.2 \pm 3.4$ & $26 \pm 4.5$ \\
\hline Red deer & $0.6 \pm 0.4$ & $2 \pm 0.9$ & $36.8 \pm 3.4$ & $8.4 \pm 4.5$ \\
\hline $\mathrm{P}$ & 0.11 & 0.46 & 0.0011 & 0.024 \\
\hline \multicolumn{5}{|c|}{ Annual grasses } \\
\hline Cattle & 0 & $1.0 \pm 2.0$ & $22.6 \pm 3.4$ & $1.4 \pm 0.6$ \\
\hline Red deer & 0 & $18.2 \pm 2.0$ & $10.4 \pm 3.4$ & $0.4 \pm 0.6$ \\
\hline $\mathrm{P}$ & - & 0.0003 & 0.04 & 0.24 \\
\hline \multicolumn{5}{|l|}{ Forbs } \\
\hline Cattle & $10.6 \pm 2.3$ & $5.2 \pm 2.4$ & $2.0 \pm 1.9$ & $9.2 \pm 3.2$ \\
\hline Red deer & $15.4 \pm 2.3$ & $9.4 \pm 2.4$ & $3.2 \pm 1.9$ & $21 \pm 3.2$ \\
\hline $\mathrm{P}$ & 0.17 & 0.25 & 0.68 & 0.03 \\
\hline
\end{tabular}

${ }^{\mathrm{T}}$ Deer-fenced red deer and beef cattle 2,500-ha ranch was the study site. Botanical composition of diets was estimated from microhistological analysis on fecal samples of red deer (Cervus elaphus) and beef cattle (Bos taurus).

${ }^{2}$ Periods sampled: Period $1=1994 / 95$; Period $2=1996 / 97$. Season by animal species by plant species class interactions were detected $(\mathrm{P}<0.01)$. Diet means are presented by plant species class and animal species within season and period.

${ }^{3} \mathrm{P}=$ Probability value of $\mathrm{F}<$ Fo for column means within plant species class.

shrubs and annual forbs, while cattle based their diet on perennial grasses (Table 2).

In 1994, shrubs and forbs made up for most of the red deer diet $(88 \%)$, and about $20 \%$ of the cattle diet $(\mathrm{P}=0.01)$. In fall of 1996, shrubs remained relevant in red deer diets, and forbs were present in much lower proportions (Table 2). No differences were detected $(\mathrm{P}=0.17)$ between animal species. Proportions of cattle diets comprised by these 2 plant speies were similar ( $\mathrm{P}>0.45)$ in fall of 1994 and 1996. Condalia microphylla, Prosopis caldenia, and Ephedra triandra were the major shrub constituents, Conyza bonar iensis and Chenopodium albun, the major forb constituents of diets.

Perennial grasses accounted for less than $10 \%$ of the diet of red deer and up to $78 \%$ cattle diet in fall of 1994 (Table 2). Graminoid proportions increased to $42 \%$ in the deer diet, and comprised again most of the cattle diet $(77 \%)$ in fall of 1996. This increment could have been associated with preceding environmental factors, such as greater summer and fall soil water in 1996, which resulted in early fall regrowth of cool-season perennial grasses. Piptochaetium napostaense, Stipa tenuis, Poa ligularis, and Hordeum stenostachis were the major cool-season perennial grasses, and Sporobolus cryptandrus was the major warm-season perennial grass found in cattle diets during fall.

Annual grasses proportion in diets were twice as large $(P=0.02)$ in cattle compared with deer in fall of 1994. The reduced size of this fraction, however, made this class of negligible biological significance.

\section{Winter diets}

Proportion of shrubs were greater $(\mathrm{P}=$ 0.003 ) in deer diets than in cattle diets during winter of 1994. Shrubs accounted for about $40 \%$ of the deer diet and less than $10 \%$ of the cattle diet. Condalia micro phylla, Ephedra triandra, Lycium sp, and Prosopis caldenia comprised most $(92.5 \%)$ of the deer diet in this season. During winter of 1996, the proportion of grasses increased and the proportion of shrubs decreased in deer diets. Despite the decline, shrubs remained a relevant class in deer diets (Table 2).

Proportion of cool-season perennial grasses comprised a large fraction of deer and cattle diets in both winters (Table 2). Differences between the 2 animal species were evident $(\mathrm{P}<0.01)$. This class accounted for most of cattle diets in both years, and sheared its importance with other classes in red deer diets. Piptochaetium napostaense and Stipa tenuis were the main grasses involved in winter diets of both animal species and periods. Hordeum stenostachys and Stipa gynerioides were especially relevant in cattle diets in winters of 1994 and 1996, respectively.

Proportions of warm-season perennial grasses in winter diets of cattle and deer in both periods were of little importance (Table 2). Sporobolus cryptandrus, Muhlenbergia sp., Digitaria californica, and Setaria leucopila were the main species of this plant class detected in winter diets.

Proportions of forbs were greater $(\mathrm{P}<$ 0.01 ) for winter of 1994 than for winter of 1996 in the diet of both animal species. Differences in proportions in the diet between deer and cattle were not detected $(\mathrm{P}>0.25)$ for forbs in either period. Baccharis gilliesii, Hyalis argentea, Plantago patagonica, Nierembergia aris tata, and Baccharis ulicine were the main forbs in winter diets of 1994, whereas, Sphaeralcea crispa was the main one in winter diets of 1996.

Proportions of annual grasses in winter diets were variable and year dependant. Proportions in diets were very low and simi$\operatorname{lar}(\mathrm{P}=0.97)$ between animal species in 
winter of 1994. In contrast, proportions were greatly different $(\mathrm{P}<0.001)$ in deer and cattle diets during winter of 1996. Cattle included very little of annual grasses in their diet during winter of 1996, while deer made of it an important class (Table 2). Bromus brevis was the major component of the annual grasses group in this season.

\section{Spring diets}

Proportions of shrubs were greatly different $(\mathrm{P}=0.01)$ in diets of deer and cattle in spring of 1994. Shrubs accounted for half of the deer diet and a minor fraction of the cattle diet. (Table 2). Shrub proportions in the diet of red deer for spring of 1996 were lower than for spring of 1994. Conversely, shrub proportions in the diet of cattle were greater for spring of 1996 than for spring of 1994. Despite the decline, this plant class remained more important $(\mathrm{P}=0.07)$ in the deer diet than in the cattle diet. Prosopis caldenia accounted for more than $85 \%$ of the shrubs consumed by deer in both springs. Condalia microphylla, Ephedra triandra, and Lycium sp, completed the remaining fraction. Ephedra triandra was the main shrub in cattle diets, followed by Prosopis caldenia and Lycium sp.

Proportions of cool-season perennial grasses were different $(\mathrm{P}<0.001)$ between animal species in spring diets. This plant class comprised less than $5 \%$ of the red deer diet in spring of 1994 and $20 \%$ in spring of 1996. In contrast, cool-season perennial grasses comprised almost half of the cattle diets in both periods (Table 2). Spring diets of both animal species included Stipa tenuis, Piptochaetium napos taense, Poa ligularis, Hordeum stenos tachys among the preferred plant species. Cattle diet included also regrowth of Stypa gynerioides in spring of 1996.

Proportions of warm-season perennial grasses in diets were similar $(\mathrm{P}=0.55)$ between animal species in spring of 1994, and accounted for about $33 \%$ of the diets. In contrast, proportions of this class were greater $(\mathrm{P}<0.01)$ in red deer than in cattle diets in spring of 1996. This reversed trend in selection of grasses for cattle and deer, could be explained by the high quality regrowth of warm-season perennial grasses in spring and the declining quality of other grasses. Sporobolus cryptandrus, Digitaria californica, and Setaria leucopila were the most important species that comprised this class. Increased share of warm-season perennial grasses in the deer diets during the second period was coincident with increased proportion of Digitaria californica.

Proportions of forbs in diets of both ani- mal species were low in spring. No differences between red deer and cattle diets were detected in the fraction accounted by forbs during spring of $1994(\mathrm{P}=0.44)$ and spring of $1996(\mathrm{P}=0.68)$.

Annual grasses were a minor fraction in diets of both animal species during spring. No differences were detected $(P=0.22)$ in this fraction between deer and cattle diets in spring of 1994, but differences were found $(P=0.04)$ in spring of 1996. Similar to the previous season, Bromus brevis comprised most of this plant class in this season.

\section{Summer diets}

Proportions of shrubs in deer diets were twice as large $(\mathrm{P}<0.01)$ as in cattle diets in both summers. Prosopis caldenia accounted for $67 \%$ of the shrub fraction in the deer diet in summer of 1995. Condalia microphylla and Prosopis caldenia accounted for 48.5 and $25.9 \%$ of the shrub fraction consumed by deer in summer of 1997. The low proportion of shrubs in cattle diets in summer of 1997 would be consistent with a more humid year, compared with summer of 1995. An increased use of caldén pods by cattle and deer was identified in summer of 1995. Year 1995 was particularly dry compared with 1996 (Table 1) and, although not measured, caldén trees may have produced a more than normal amount of fruits.

Proportions of cool-season perennial grasses in the diet of cattle were about 4 times $(\mathrm{P}<0.01)$ the proportion found in deer diets in both summers (Table 2). Cattle based about half of the summer diet on this forage class. These observations indicate that cattle maintained high consumption of cool-season perennial grasses during summer, whereas, deer declined use of this grasses class as they matured. Piptochaetium napostaense and Stipa tenuis constituted the main cool-season perennial grasses for red deer and cattle diets in summer of 1995. Both plant species comprised about equal proportions of their class in the diet of each animal species (42 and $40 \%$ in the deer diet; 37 and $35 \%$ in the cattle diet, respectively). Conversely, Piptochaetium napostaense comprised 98 and $94 \%$ of the class in red deer and cattle diets, in summer of 1997.

Proportions of warm-season perennial grasses were important in deer and cattle diets during summer of 1995, and no differences were detected $(\mathrm{P}=0.53)$ between animal species. Relative importance of this class decreased during the summer of 1997 but differences between the 2 animal species were significant $(\mathrm{P}<0.05)$. Sporobolus cryptandrus, was the main component of the warm-season perennial grasses class in both summers.

Proportions of forbs were low and similar $(\mathrm{P}=0.93)$ in diets of both animal species in summer of 1995 . Forbs became more important in diets of summer of 1997. Differences $(P<0.01)$ between red deer and cattle diets in forb proportions were detected in this season. Sphaeralcea crispa was the major forb component of this class. Water availability may have been the largest contributing factor to a greater forb presence in diets during summer of 1997. Annual grasses had a negligible participation in summer diets of red deer and cattle in both periods.

\section{Seasonal differences by animal species}

Red deer based their diet on shrubs and forbs in fall (Table 2), over periods. During winter, consumption of cool-season perennial grasses by red deer increased when compared with fall consumption $(\mathrm{P}<0.01)$, and the proportion of forbs declined $(\mathrm{P}<0.01)$. In spring and summer, red deer based their diet on shrubs and the perennial graminoid classes. Warm-season perennial grasses level averaged 34 and $25 \%$ in the spring and summer diets, respectively. Annual grasses were relevant in spring diets of both periods and in winter of Period 2.

Cattle based their diet on perennial graminoids. Cool- and warm-season perennial grasses together comprised $70 \%$ or more of cattle diets in all seasons (Table 2). Forbs and shrubs were always present in cattle diets and were consumed as complementary forages, second to perennial grasses. Forbs were relevant in fall and winter diets over periods. Shrub class proportions in cattle diets were more important in spring and summer than in fall and winter (Table 2). Annual grasses showed an increased presence in spring of both periods sampled. Importance of this class in other seasons was low and year depending.

\section{Diet overlap}

Diet overlap between the 2 animal species varied with periods and seasons. Period 1 showed larger $(\mathrm{P}<0.05)$ changes in diet overlap than Period 2. Low overlaps resulted in fall (14.2\%) and spring $(27.4 \%)$ of Period 1. Cool-season perennial grasses and forbs or shrubs were the main classes responsible for diet differences in fall. Cool-season perennial grasses and shrubs were the main classes responsible for diet differences in spring. Compared with fall and spring, overlap was greater $(\mathrm{P}<0.01)$ in the other 2 sea- 
sons (56.8 and $62.6 \%$ for winter and summer, respectively). In contrast with Period 1 , Period 2 showed the greatest overlap in fall, which decreased $(\mathrm{p}=0.09)$ progressively over winter and spring (56.8, 52.0, and $49.2 \%$, respectively). Summer of 1996 showed the lowest overlap of this period with a significant drop to $33.8 \%$, greatly different $(\mathrm{P}<0.01)$ from the other 3 seasons. It appeared that a more humid year increased the importance of perennial grasses in deer diets during fall and spring. Still, shrubs comprised more than $50 \%$ of the deer diet in summer of 1997, whereas grasses comprised $84 \%$ of the cattle diet in the same season.

\section{Discussion}

Body size, anatomy, and ingestivedigestive physiology of each herbivorous species characterize the grazing strategy and define selectivity patterns (Schwartz and Ellis 1981). Body size of ruminants has a direct effect on forage selection. Larger herbivores are less selective than smaller ones. Total daily requirements of energy of large herbivores are greater and animals tend to harvest more fibrous diets (Schwartz and Ellis 1981, Gordon and Illius 1988, Illius and Gordon 1987, 1989). Smaller animals have faster metabolic rates, they have to eat higher quality foods than larger animals, but require less food. Narrow dental arcades correspond generally with high selection ability (Gordon and Illius 1988). In several animal species, combination of diet selection skills, moderate body size, and ease of movement add a competitive advantage to survival. Gordon and Iason (1989) placed red deer as an intermediate selector, between cattle and goat. These authors consider red deer to have lower capacity than cattle for digesting low quality forages, but a superior ability in browsing and grazing on good quality plant parts. Consequently, these different skills of herbivores change the potential use of plants and the nutritive value of diets.

Quantification of diets using microhistology of feces may be compromised by differential digestion of plant fractions and dicernability limitations of fragments in fecal analysis. Although actual quantification of diets could have been biased in this study, cattle and red deer potential biases because of digestion should equal out. So, basic comparative conclusions would be valid (Vavra and Holechek 1980), and use of this tool generated information otherwise unfeasible. Red deer and cattle diets differed throughout the year, given forage availability and plant species diversity with potential for browsing or grazing. Albeit interactions exist, a superior browsing activity for red deer, compared with cattle was shown. Across years, shrubs accounted for 28 to $50 \%$ of deer diets in most seasons, and from 6 to $12 \%$ in cattle diets. Red deer consumed more than 4 times the amount of shrubs observed for cows during all seasons. Relative importance of shrubs in the deer diets decreased in winter, when cool-season perennial grasses increased from fall season levels.

According to microhistology, proportions of forbs in diets were highly variable. Red deer consumed more forbs than cattle in most seasons $(\mathrm{P}<0.05)$, however, no consistent trends could be defined. Forbs accounted for more than $50 \%$ of deer diet and $14 \%$ of the cattle diet $(\mathrm{P}<$ 0.01 ) in fall of 1994. Differences were also evident $(\mathrm{P}<0.01)$ in summer diets. Although these effects are greatly circumstantial and year dependant, they suggest red deer exhibit a selection ability for highly palatable species. Importance of forbs in fall diets has also been reported by Kinuthia et al. (1992).

Cattle utilized more perennial grasses than red deer in all seasons, and based their diet on cool-season species. Cattle diets contained 3 times the amount of perennial grasses than deer diets in fall, spring and summer, and almost twice the amount in winter. Within the grasses classes, red deer seemed more selective than cattle. Differences between both animal species in relative proportions of major components within cool- and warmseason classes of perennial species, would suggest a greater selection of red deer for more palatable grasses. Similarly, Ellis et al. (1976) reported high sensitivity of deer to plant species, quality and phenological stage. Both animal species exerted a minor and complementary utilization of annual winter and summer grass, including Bromus brevis, Hordeum stenostachys, Cynodon dactylon, and Digitaria califor nica. The presence of these grasses is highly dependant on soil moisture conditions and the soil seed bank.

Research conducted in South-central Wyoming (Kinuthia et al. 1992) concluded that mule deer (Odocoileus hemionus hemionus) and pronghorn (Antilocarpa americana) behaved as browsers, and elk (Cervus elaphus), cattle (Bos tourus) and sheep (Ovis aries) as grazers. Results from our work would indicate that, in Argentinean central caldén forest, red deer behave as intermediate feeders or as graz- ers depending upon presence of palatable species. A trend for red deer behaving as an intermediate feeder, compared with cattle could be suggested.

Observations showed also that deer and cattle diet overlap varies greatly depending diversity of forage on offer and availability of palatable fractions of forbs, shrubs, and grasses. Plant species diversity and presence of forb and shrub regrowth would reduce diet overlap in the environment of this study. A fairly diverse forage supply (trees, shrubs, forbs, and grasses) would allow red deer to collect a highquality diet throughout the year. Browsing on trees and shrubs, added to the use of forbs and grasses during the growing period, would give red deer a strong competitive advantage. Similar results were obtained by Young (1938) and Kufeld (1973). Balmaceda and Digiuni (1983) described a similar browsing behavior for goats, differing from cattle, guanaco, and sheep. According to our results, introduction of red deer would increase browsing pressure on shrubs and low trees, which could result in a management tool for brush control. Similar roles of ungulates in shrub control strategies have been mentioned for goats in the literature (Olson and Hansen 1977, Hansen 1982, Kinuthia et al. 1992).

It is possible that certain environments could tolerate higher stocking rate with both, cattle and red deer, than with only one of them. Results would indicate that cattle and red deer could be integrated in production programs for the region without a large degree of competition. Management of red deer in deer-fenced operations with cow-calf programs will depend on the total carrying capacity based on grass production and the structure of the shrub population present. Management strategies for deer and cattle in this region, defined for cattle use, may overestimate grass utilization potential and underestimate quality required by red deer. On the other hand, underestimation of shrub offer and deer use of this plant species class may result in lower than optimal stocking. Fields with grass for cattle, few shrubs and trees could be classified as poor range for red deer. In contrast, fields with a less productive grass component, disturbed areas, and dense shrub mass may be better suited for red deer than for cattle. More research on compared feeding behavior, diet overlap and preferences under different stocking rates, and requirements of integrated systems is necessary to better define potential and limits of cattle and red deer production programs. 


\section{Literature Cited}

Balmaceda, N. A. and J. N. P. Digiuni. 1983. Estimación de la dieta de vacunos, ovinos, caprinos y guanacos en la zona del monte por el método micro-histológico. Prod. Anim. 10:265-272.

Cano, E. 1980. Subregión de las mesetas y valles. Inventario integrado de los recursos naturales de la Provincia de La Pampa. INTA-GPLPam.-UNLPam. 493 pp.

Ellis, J. F., A. Wiens, C. F. Rodell, and J. C. Anway. 1976. A conceptual model of diet selection as an ecosystem process. J. Theor. Biol. 60:93-108.

Gordon, I.J. and G.R. Iason. 1989. Foraging strategy of ruminants: Its significance to vegetation utilization and management. The Macaulay Land Use Research Institute Annual Report 1988-1989. p. 35.

Gordon, I. J. and A. W. Illius. 1988. Incisor arcade structure and diet selection in ruminants. Functional Ecol. 2:15-22.

Hansen, R. M. 1982. Diets of mule deer, pronghorn and antelope, California bighorn sheep, domestic cattle and feral horses in northwestern Nevada. USDA Fish and Wildl. Serv., Lakeview. Ore.
Holechek, J. L. and B. D. Gross. 1982. Evaluation of diet selection in ruminants. Functional Ecol. 2:15-22.

Holechek, J. L., M. Vavra and R. D. Pieper. 1982. Botanical determination of range herbivore diets: a review. J. Range Manage. 35:309-315.

Illius, A. W. and I. J. Gordon. 1987. The allometry of food intake in grazing ruminants. J. Anim Ecol. 56:989-100.

Illius, A. W. and I. J. Gordon. 1989. Prediction of size-scaling effects on forage intake and digestion using a model of digesta flow in ruminants. Anim Prod. 48:637.

Kinuthia, R., J. Powell, F. C. Winds and R. A. Olson. 1992. Range animal diet composition in south-central Wyoming. J. Range Manage. 45:542-545.

Kufeld, R. C. 1973. Foods eaten by the Rocky Mountain elk. J. Range Manage. 26:106-113.

Müeller-Dombois, D. and H. Ellenberg. 1974. Aims and methods of vegetation ecology. J. Wiley \& Sons, New York, N.Y.

Olsen, F. W. and R. W. Hansen. 1977. Food relations of wild free-roaming horses to livestock and big game, Red Desert, Wyoming. J. Range Manage. 35:152-164.
Roberto, Z. E., G. Casagrande and E. F. Viglizzo. 1994. Lluvias en la pampa central. Tendencias y variaciones del siglo. Cambio climático y agricultura sustentable en la región pampeana. PEI Ed. INTA 2:3-25.

SAS, 1985. SAS User's Guide: Statistics. SAS Inst., Inc., Cary, N.C.

Schwartz, C. C. and E. Ellis. 1981. Feeding ecology and niche separation in some native domestic ungulates on the shortgrass prairie. J. Appl. Ecol. 18:343-353.

Sparks, D. R. and J. C. Malechek. 1968. Estimation percentage dry weight in diets using a microscopic technique. J. Range Manage. 21:264-265.

Vavra, M. M. and J. C. Holechek. 1980. Factors influencing microhistological analysis of hervibore diets. J. Range Manage. 33: 335-371.

Vavra, M. M., M. McInnis, and D. Sheehy. 1989. Implications of dietary overlap to management of free-ranging herbivores. Proc. West. Sec. Amer. Soc. Anim. Sci. 40:489-495.

Young, V. A. 1938. The carrying capacity of big game range. J. Wild. Manage. 2:131-134. 